\title{
Kafkasya'da Ruslaştırma Siyaseti (XIX. Yüzyıl ve XX. Yüzyıl Başları)
}

\author{
Mustafa Tanriverdi ${ }^{*}$
}

\section{Özet}

XIX. yüzyılda sınırlarını Kafkasya ve Türkistan'a uzatan Rusya İmparatorluğu, Slav kökenli olmayan nüfusunu da arttırmış oldu. Bu yapıyı bir arada tutmanın yollarını arayan Rusya, din ve dil alanlarındaki farklılıkları XIX. yüzyılın sonlarına doğru kaldırmayı amaçladı. Artan Rus milliyetçiliğinin ve siyasi gelişmelerin ortaya çıkardığı bu tutum, Rusça literatürde "Rusifikatsiya" yani "Ruslaştırma" olarak adlandırılmaktadır. Bu politika bağlamındaki uygulamalar, bazı Rus bürokratlara göre uygar bir toplum yaratmayı amaçlıyordu. Bazılarına göre ise, Ruslaştırma değil Ruslaşma olarak gerçekleşen eylemler de vardı. Ruslaşma, kendisini iktidar ve gücün yanında göstermek isteyenlerin tercihi olarak ortaya çıkıyordu. Bu gruplar, devletin kimliğine ve ideolojisine bağlılık gösteriyor ve kendisini bir süre sonra Rus olarak tanımlıyordu.

Ruslaştırma siyaseti, Kırım Savaşı sonrası yükselen Rus milliyetçiliğinin yansıması olarak kendini göstermeye başladı. II. Aleksandr'ın 1881'de suikasta kurban gitmesinin ardından, Rusya sınırları içerisindeki farklı kimlikler düşman olarak algılanmaya başlandı. Kafkasya gibi çok uluslu yapıya sahip bölgede, sorunlar ve devletin tepkileri önemli gelişmelere yol açtı. Ruslaştırma politikasının din ve eğitim alanındaki yansımaları, Rus olmayanların isyana varan eylemleriyle sonuçlandı. Rusya, 1905 İhtilalinin ardından Ruslaştırma siyasetinden bir süreliğine geri adım atmak durumunda kaldı.

Bu çalışmada, Ruslaştırma siyasetinin ne gibi sonuçlar doğurduğu üzerinde durularak, Kafkasya'daki milliyetçilik ve bağımsızlık hareketleri üzerindeki etkileri incelendi. Bütün bu gelişmeler Rusça arşiv kaynakları ve literatür yardımıyla değerlendirilmeye çalışıldı.

Anahtar Kelimeler: Ruslaştırma, Kafkasya, Rusya, Rus, Ermeni

Yrd. Doç. Dr., İstanbul Üniversitesi Edebiyat Fakültesi Tarih Bölümü, mustafatanriverdi36@gmail.com. (ORCID ID: 0000-0003-1307-5354). (Makale Gönderim Tarihi: 28.06.2017, Makale Kabul Tarihi: 15.09.2017).

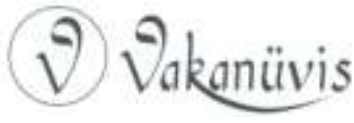




\section{Russification Policy In Caucasus (XIXth and Early XXth Century)}

\section{Abstract}

The Russian Empire, which ruled over an area from the Caucasus to Central Asia, also hosted a significant portion of non-Slavic population throughout the nineteenth century. Looking for ways to keep this demography together, Russia aimed to get rid of differences in areas of religion and language by the end of the century. This attitude, which emerged from a growing Russian nationalism and political developments, is called "Rusifikatsiya" in Russian historiography. According to some Russian bureaucrats, the practices in this policy aimed at creating a civilized society. According to others, these policies were not a form of Russification but just an acculturation into Russian culture, i.e. Ruslation. Ruslation was carried out by those who wanted to show themselves with power, and connected themselves to the identity and ideology of the state.

The Russification policy began to manifest itself as a reflection of the rise of Russian nationalism after the Crimean War. After the assassination of II. Aleksandr's in 1881, different identities within Russian borders began to be perceived as enemies. In the region with a multinational structure like the Caucasus, problems and reactions of the state led to significant developments. Reflections of the Russification policy in the field of religion and education resulted in the revolt of non-Russian actions. After the 1905 Revolution, Russia had to step back from the Russification policy.

This study will examine the effects of the Russification policy on nationalism and independence movements in the Caucasus. All these developments were tried to be evaluated with the help of Russian sources.

Keywords: Russification, Caucasus, Russia, Russian, Armenian

Rusya İmparatorluğu, nüfus yapısı itibariyle çok uluslu bir karaktere sahipti. Imparatorluğun doğu ve güney bölgelerinde Fin ve Türk kabileler ile çoğunluğu Müslüman olan halklar yaşıyordu. 1897 Genel Nüfus Sayımına göre; toplam nüfus içerisinde Ortodoks mezhebine mensup olanlar nüfusun \% 70,8'ini, Katolikler \% 8,9'unu, Müslümanlar \% 8,7'sini, Protestanlar \% 5,2'sini, Yahudiler \% 3,2'sini, Heterodoks gruplar \% 1,4'ünü, Ermeni-Gregoryanlar \% 0,8'ini oluşturuyordu. Kafkasya'da toplam nüfusun \% 41,7'sini Müslümanlar oluştururken, bu oran Orta Asya'da \% 89,7'ye varıyordu. Polonya'da toplam nüfusun \%

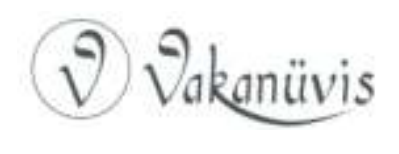


76,5'i Katoliklere aitti. Yahudi nüfus Polonya'da, Protestanlar Finlandiya'da yoğunlaşıyorlardı. ${ }^{1}$

Etnik bakımdan Rus ve Slav olmayan milletler arasında Hıristiyan olan Gürcü, Ermeni, Fin ve Müslüman olan milletler bulunuyordu. Imparatorluğun Kafkasya halkları üzerindeki politikası insana, mekâna ve zamana göre değişiklik gösterebilmekteydi. Yönetimin halklara yaklaşımı eşit mesafede değildi. ${ }^{2}$

"inorodtsı" kelimesi imparatorluğun Slav olmayan halklarını tanımlamak için kullanılıyordu. Osmanlıdaki "gayr-i Müslim" kelimesi dini bir karakter taşırken, bunun Rusya'daki karşılığı sayılabilecek "inorodtsı" kelimesinin etnik anlamı öne çıkıyordu. Rus kökenli olmanın devlet kurumlarında ve hukuk alanında ayrıcalıkları vardı. Diğer milletler, hâkim Rus anlayışııın baskısı altında yaşamak durumundaydı. $\mathrm{Bu}$ anlamda Rus veya Slav kökenlilerin, İmparatorluğun diğer halkları "inorodtsı" lar üzerinde bir hegemonyası veya deyim yerinde ise "tepeden bakma" sı söz konusu idi. Slav olmayan, ancak Hıristiyan olanlar "inorodtsı" olarak sayılmakla birlikte, Müslümanlara göre daha rahat bir yaşama sahiplerdi. Devletin sunduğu eğitim başta olmak üzere diğer sosyal hizmetlerden Müslümanlara oranla daha iyi şartlarda faydalanabiliyorlardı. Rus olmayan milletler, yönetim ile sorunları olmadığını ilan eder ve onun hâkimiyetini kabul eder ise, bir takım imtiyazlar ile ödüllendiriliyordu. Ancak eğer tabi olunmuyorsa iktidar bunu bir tehdit olarak algllıyor ve askeri gücünü devreye sokuyordu. ${ }^{3}$ Farklı etnik ve dinî aidiyetlere mensup insanlar, "Rus ideali" ile tam bir uyum içerisinde çalıştığında, bürokrasi ve orduda

\footnotetext{
${ }^{1}$ Rossiya Entsiklopediçeskiy Slovar, Leningrad 1991, s. 86.

2 Zahida Alizade, “Natsional'no-Kolonial'naya Politika Tsarskovo Pravitel'stva na Tsentral'nom Kavkaze", Kavkaz i Globalizatsiya, Cilt: 1, Sayı: 5, 2007, s. 162.

3 Dmitriy Alekseyeviç Nikotin, "Natsional'nıy Faktor Transformatsii Politiçeskogo Rejima v Rossii: İstoriçeskiy Opıt i Sovremiyennost'”, İstoriçeskiye, Filosofskiye, Politiçeskiye i Yuridiçeskiye Nauki, Kul'turologiya i Iskusstvovedeniye. Voprosı Teorii $i$ Praktiki, Sayı: 7-2 (57), 2015, s. 118.
}

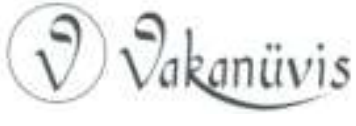


görev alabiliyordu. ${ }^{4}$ Rus kültürü ve özellikle Rus Ortodoksluğu her şeyin üstünde görülüyordu. ${ }^{5}$

Rusya, özellikle XIX. yüzyılın ikinci yarısından itibaren tek uluslu bir toplum inşası için Ortodoks ve Rus olmayan halklar üzerinde Rusça literatürde "Rusifikatsiya" diye adlandırılan Ruslaştırma siyasetini izledi. $^{6}$ "Rusifikatsiya", farklı anlama sahip iki ayrı kelime ile tanımlanıyordu. Bu kelimelerden ilki "obrusit", ikincisi ise "obruset" " idi. Obrusit" kelimesi iktidar eliyle Ruslaştırma anlamına geliyordu. Obruset' ise, kendi isteği ile Ruslaşma çabasını ifade ediyordu. ${ }^{7}$ ilkinde, devletin temel politikası, iletişim ve düşüncede birliği sağlamaya yönelikti. Bunun için en önemli araç dil olarak görülüyordu. Bu düşünceyi savunan narodnik (halkçı) L. A. Tihomirov, ülkedeki farklı yapıların ve kültürlerin birbirine ilim yolu ile bağlanabileceği inancına sahipti. Bunu sağladıktan sonra milli ekonomi gibi alanlarda da rahatça adım atılabilirdi. Tihomirov tek dil, tek din ve tek bilim anlayışı ile tek bir ruh oluşacağına inanıyordu. ${ }^{8}$

Rusifikatsiya politikası ile Rusya İmparatorluğu'nun bütünlüğünü sağlamanın amaçlandığını öne süren tarihçi Aleksey illiç Miller, Rusya'nın devlet milliyetçiliği ile bünyesinde yaşayan diğer etnik grupların ayrılık heveslerini önlemeye çalıştığının altını çiziyordu. ${ }^{9} \mathrm{Bu}$ anlamda, Rus dili ve kültürünün yoğun olarak öne çıkarılması ve farklı etnik gruplar üzerinde artan baskı, politikanın esas karakterini ortaya koyuyordu. ${ }^{10}$

\footnotetext{
${ }^{4}$ F. H. Şebzuhova, "Osobennosti Upravleniya Natsional'nımi Okrainami v Rossiyskoy Imperii na Rubeje XIX-XX vv", Ejekvartalnıy Retsenziruemıy Nauçnıy Jurnal "Vestnik AGU", Sayı 3 (184), 2016, s. 35.

${ }^{5}$ Weeks R. Thedore, "Russification: Word and Practice 1863-1914", Proceedings of the American Philosophical Society, Cilt 148, Sayı: 4, Aralık 2004, s. 471.

${ }^{6}$ Istoriya XIX Veka, Editörler: Lavissa ve Rambo, Cilt: 8, Moskva 1939, s. 296.

${ }^{7}$ Aleksey Miller, Imperiya Romanovih i Natsionalizm, Moskva 2014, s. 61.

${ }^{8}$ V. N. Kudryaşev, "Konservativno-Utopiçeskaya Interpretatsiya Rusifikatorskoy Politiki v Kontse XIX-Naçale XX v", Vestnik Tomskogo Gosudastvennogo Universiteta, Sayı: 296, Tomsk 2017, s. 97.

${ }^{9}$ Viktor Borisoviç Kior, "Gosudarstvennaya Natsional'naya Politika v İmperskoy Rossii", Vestnik Rossiyskogo Gosudarstvennogo Gumanitarnogo Universiteta, Sayı: 4, Moskva 2010, s. 206.

${ }^{10}$ E. G. Lufyerçik, "Rusifikatsiya Kak Sredstvo Reşeniya Pol'skogo Voprosa Vo Vtoroy Polovine XIX-Naçale XX v.", Vesnik BDU, Sayı 3, s. 23.
}

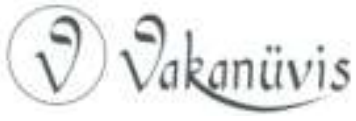


"Rusifikatsiya" ile "asimilasyon" kavramları arasında bazı benzerlikler bulunmakla birlikte, kendine özgü bir takım farklılıklar barındırmaktadır. "Rusifikatsiya" politikasının esas amacı, Rus kültürünü özümsetme olarak açıklanıyordu. "Asimilasyon" ise bu özümseme sürecini, kendiliğinden ve farkında olmadan gerçekleştiriyordu. Bazı yazarlar "Rusifikatsiya" yı bir "kültür soykırımı" olarak da tanımlamanın mümkün olduğunu iddia etmektedir. ${ }^{11}$

Rus milliyetçileri "Rusya Ruslarındır" düşüncesinde, Ruslaştırma idealini savunanlar ise; etnik milliyetçiliği göz ardı ederek Ruslar dışındakileri tamamen yok saymak yerine, onları Ruslaştırarak sisteme dâhil etmeyi amaçlıyorlardı. Milliyetçiler, devletin her noktasında yalnızca Rus kökenlileri görmek istiyorlardı. Onlara göre, "Rusya Ruslarındır" gibi sloganlar, Rus kökenli olmayanlara karşı düşmanca bir tutumdan kaynaklanmıyordu. ${ }^{12}$

XIX. yüzyıldaki gelişmeler, devletin toplum ile ilişkisine yön veriyordu. Kırım Savaşı ile farklı bir boyut kazanan Rus Milliyetçiliğinin, devlet içerisinde yükselmesi II. Aleksandr döneminde etkilerini göstermeye başlamıştı. 13 "Rusya Ruslarındır" sloganı, 13 Mart 1881'de II. Aleksandr'ın Petersburg'da bir suikast sonucu öldürülmesinin ardından daha da dillendirilir oldu. 29 Nisan 1881'de otokrasinin güçlendirilmesi amacıyla bir bildiri yayınlandı. Bu bildiriyi 14 Ağustos 1881 'de "düzenin sağlanması için özel önlemler getiren kanun" un kabulü izledi. Bu kanun ile devletin güvenliği ve kamu düzenini sağlamaları için valilere olağanüstü yetkiler verildi. Bu sayede merkezden uzak bölgelerde asayişin sağlanması ve iç karışıklıkların yayılmasını engellemek hedeflendi. III. Aleksandr, iktidarının ilk yıllarında buna benzer kararlar almaya devam etti. Liberal bakanlar ve idarecileri görevden aldı ve yerlerine kendi ideolojisine yakın

\footnotetext{
11 Aleksandr Şelkaçev, "Obsujdeniye na Predsobornom Prisutstvii Voprosa ob Avtokefalii Gruzinskoy Tserkvi", Yejegodnaya Bogoslovskaya Konferentsiya Pravoslavnogo Svyatotihonovskogo Gumanitarnogo Universiteta, Sayı: 22, Moskva 2012, s. 50.

${ }^{12}$ A. A. İvanov, "Lozung «Rossiya dilya Russkih» v Konservativnoy Mısli Vtoroy Polovinı XIX Veka”, Tetradi Po Konservatizmu”, Sayı: 4, Moskva 2015, s. 34-41.

${ }^{13}$ Kior, a.g.m., s. 207.
}

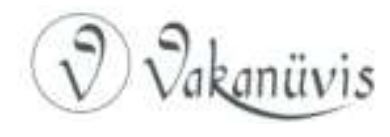


durabilecek kişileri atadı. 1881 yılı Mayıs ayında İçişleri Bakanı LorisMelikov istifa etti ve yerine Nikolay Pavloviç İgnatyev geçti. ${ }^{14}$

III. Aleksandr dönemi tarihçilerinden V. V. Nazarevskiy, Çar'ın Rus tarihi ideali ile sıkıca bütünleştiğinden ve "Rusya Ruslar içindir" düşüncesinde olduğundan bahsetmektedir. ${ }^{15} \mathrm{III}$. Aleksandr, Rusça'nın yayılması ve Ortodoksluk inancına saygının sağlanması ile Rus hâkimiyetinin güçleneceğine inanıyordu. Milli politika sayesinde devletin hem iç hem de dış güvenliğinin sağlanacağı düşüncesine sahipti. Bu politika, devletin birçok kurumunda ve yönetim biçiminde bir takım yenilikler yapmayı gerektiriyordu. ${ }^{16}$

Yapılacak değişikliklerin imparatorluğun uç bölgelerinde, bilhassa Kafkasya ve Polonya gibi yerlerde daha etkili sonuçlar vermesi için buralarda idari yapı değişiklikleri gerçekleşti. Kafkasya'da 1882'de Kafkasya Genel Valiliği ihdasına gidildi ve 1905 yılında naibliğin tekrar kabulüne kadar bölge bu idari yapı ile yönetildi. Sınır bölgelerinde idarecilerin yönetme yeteneği büyük önem arz ediyordu. Rusya Hükümeti bu bölgelerde yerel yöneticilerin yerel elitler ile işbirliği içerisinde olmalarını istiyordu. Bu elitlerin daha sonra yerel yöneticilerin kontrolünde, yerel halk üzerinde etkide bulunmaları bekleniyordu. Yerel yöneticilerin yanı sıra bilgisine başvurulacak uzmanlar ve etnik grupların temsilcileri de bu süreçte rol alıyorlardı. Askerler, din adamları, öğretmenler, doktorlar, mühendisler ve köylüler sürecin gerektirdiği şekilde katkıda bulunuyorlardı. ${ }^{17}$

1883 yılında "Kafkasya ve Zakafkasya (Güney Kafkasya) Krayı'nın Yönetiminin Yeniden Düzenlenmesi Hakkında Kanunname" yayınlandı. Bu kararname Kafkasya'nın yeni yönetiminin görev tanımlamasını içeriyordu. Kurulan yeni sistem, merkezi hükümetin bakış açısına göre hareket ederek etkili bir biçimde merkezin otoritesini sağlayacaktı. ${ }^{18}$

\footnotetext{
${ }^{14}$ Kezban Acar, Ortaçağ'dan Sovyet Devrimi'ne Rusya, İstanbul 2009, s. 292.

${ }^{15}$ İvanov, a.g.m., s. 37.

${ }^{16}$ Kior, a.g.m., s. 207.

${ }^{17}$ Kior, a.g.m., s. 212.

${ }^{18}$ N. N. Tumakov, "Pervaya Russkaya Revolutsiya i Vosstanovleniye Namestniçestva na Kavkaze”, Vestnik Ryazanskogo Universiteta Im. S.A. Yesenina, Sayı: 27, Ryazan 2010, s. 30.
} 
Kafkasya idari düzenini yerleştirme çabaları, arzu edilen şekilde sonuç vermedi. İmparatorluğun diğer bölgelerindeki idari düzenin aynısının burada uygulanması hedeflenirken, Kafkasya'nın kendine özgü karakteri buna müsaade etmedi. Bunu aşmak için soyluların nüfuzundan yararlanmak adına, onların yönetimin bazı organlarında yer almaları sağlandı. ${ }^{19}$

Kafkasya'nın, Ruslaştırma politikası ekseninde ayrı bir yeri ve önemi vardı. Kafkasya, tam da İmparatorluğun çok dilli ve dinli yapısının aynası gibiydi. XIX. yüzyıla gelindiğinde, uzun yüzyıllardır bu bölgede yaşayan ve kimliğini koruyan halklar mevcuttu. Rusya'nın XIX. yüzyıl başında Gürcistan'ı ele geçirmesi ve ardından diğer hanlıkları Imparatorluğun idari sistemiyle birleştirmesi, kolonizasyon politikasını da beraberinde getirdi. Bunu uygularken de, çoğunlukla mutlak iktidarın gücünü etkili bir şekilde hissettirecek uygulamalara imza attı.

Kafkasya'daki nüfus yapısı, XIX. yüzyılın başlarından itibaren Rusya'yı yönetim anlamında sert tedbirlere ve zaman zaman da köklü reformlara zorladı. Dağıstan ve Çeçenistan'da 1832-1859 yılları arasında iktidarı kabullenmeyen halk, radikal oluşumlar olarak gösterilmeye çalışıldı. ${ }^{20}$ Örneğin "Müridizm" hareketi, dinsizler ve Müslüman olmayanlar ile mücadele olarak tanımlanıyordu. ${ }^{21}$ Ancak, bu hareketi aşırıcı ve saldırgan göstermek isteyenlerin yanında, Çarlık emperyalizmine ve yerli feodal beylere karşı yürütülen ilerici bir mücadele olarak sunanlar da vardı. ${ }^{22}$

i̇kinci Katerina döneminde Kafkasya'yı ele geçirme planları yapan Rusya, burada Rus nüfusu yerleştirmeyi ve bununla bir kolonizasyon politikasını uygulamayı amaçladı. Bu amaç doğrultusunda Rusya'nın merkez guberniyalarından (vilayet) ${ }^{*}$ soylu ve toprak ağaları getirilerek,

19 Perihanum Ferezullayevna Ragimova, "Politika Rossiyskogo Pravitel'stva v Natsional'nıh Okrainah v XIX-Naçale XX vv.", Vestnik Krasnoyarskogo Gosudarstvennogo Pedagogiçeskogo Universiteta im. V. P. Astaf'eva, Sayı: 3, Krasnoyarsk 2010, s. 231.

${ }^{20}$ N. A. Smirnov, Politika Rossii na Kavkaze XVI-XIX vekah, Moskva 1958, s. 200.

${ }^{21}$ N. G. Georgiyeva, v.d., İstoriçeskiy Slovar', Moskva 2015, s. 338

${ }^{22}$ Abdullah Temizkan, "Kuzey Kafkasya Müridizmi, Müridizmin Yayılma Stratejisi ve Feodal Beylerle ilişkileri”, Türk Dünyası Incelemeleri Dergisi, Cilt: IX, Sayı 2, s. 166.

* "Guberniya" sözcüğü latince "gubernium" kökünden gelmektedir. "Guberniya", "guberniya şehri" veya "ana şehir" anlamında da kullanılan guberniya kavramı, Rusya

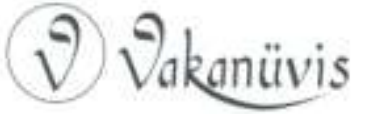


Rusya'nın kontrolünde olan Terek ve Kuban taraflarında yirmi yıllı̆ı̆ına (1785-1804) işleyebilecekleri topraklar verildi. Ayrıca bazı Kossak birliklerine de aynı imtiyazdan faydalanma imkânı tanındı. ${ }^{23}$ Rusya'nın XIX. yüzyıl başlarında Kafkasya'yı ele geçirmesi ve ardından kendi idari düzenini kurması, bölgede yeni bir dönemin başlangıcı oldu.

Bu yeni düzenin kurulması, iç ve dış aktörler nedeniyle kolay olmadı. Kafkasya, XIX. yüzyılın başlarında Rusya, İran ve Osmanlı Devleti'nin yanı sıra, İngiltere ve Fransa gibi devletlerin de doğu politikalarında öneme sahipti. Fransa Dışişleri Bakanı Talleyrand, 1804'de Napolyon Bonapart'ın uzun zamandır Rusya'nın güneye doğru yayılmasını dikkatle izlediğinden bahsediyordu. Napolyon'a göre, Rusya'nın bu ilerlemesi İran ve Türkiye gibi ülkelerin aleyhine olacak ve bu ilerleme başarıya ulaşırsa Rusya'ya karşı direnecek güç kalmayacaktı. Bu ilerlemeden duyulan endişe, Fransız ile İngiliz diplomatları ortak bir dilde buluşturabiliyordu. ${ }^{24}$

Kendisi aleyhine oluşan bu ittifakın farkında olan Rusya, Kafkasya'da hızlı bir yayılma politikası izledi. 1801'de Tiflis'e ele geçiren ve Kafkasya'nın merkezine yerleşen Rusya, bu adımdan sonra Kafkasya'nın diğer bölgelerini ele geçirmeyi amaçladı. Yüzyılın ilk çeyreğinde bu amacı doğrultusunda önemli avantajlar elde etti. Ancak, Kafkasya'nın çok etnili ve çok kültürlü yapısı, Rusya'nın yönetimde zorlanmasına neden oldu.

Rusya, Kafkasya'yı kontrol altında tutmak amacıyla idari, ekonomik ve politik anlamda tam hâkimiyet esasını amaçlıyordu. ${ }^{25} \mathrm{Bu}$ amaca ulaşmak için, çeşitli yolları deneyen Rusya, zaman zaman sert önlemler alıyor ve yerel halkı baskı altında tutuyordu. Bu tutum neticesinde XIX.

İmparatorluğu idari yapılanmasındaki yeri dikkate alındığında, Türkçeye "vilayet" olarak çevrilebilir. Osmanlı belgelerinde guberniya karşılığı olarak "eyalet" kullanılıyordu. Bazı belgelerde ise, Kafkasya'nın kendisi bir eyalet olarak kaydediliyordu. Mustafa Tanrıverdi, "Çarlık Rusyası Döneminde Tiflis Guberniyası (1878-1914)", İstanbul Üniversitesi Sosyal Bilimler Enstitüsü, Yayınlanmamış Doktora Tezi, İstanbul 2016, s. 105.

${ }^{23}$ Yelena İsaakovna Kobahidze, "K Voprosu o Roli Kolonizatsii v Politike «Rusifikatsii» Severnogo Kavkaza (Vtoraya Polovina XIX-Naçalo XX V.), Izvestiya Soigsi, Sayı: 13 (52),

Vladikavkaz 2014, s. 9.

${ }^{24}$ Smirnov, a.g.e., s. 173.

${ }^{25}$ Oçerki İstorii Gruzii Guriziya v XIX. veke, Cilt: V, Tbilisi 1990, s. 337.

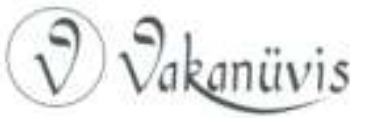


yüzyılın ilk yarısında köylü isyanları yaşandı. Yeni vergilendirme sisteminin getirdiği yükümlülüğü karşılayamayan Guri köylüsü, 1841'de isyan etti. Rusya yönetiminin vergileri Rus rublesi ile alma isteği derin rahatsızlık yarattı. Rus parasına sahip olmayan köylüler zor durumda kaldı. Bu kararın ardından kabul edilen kişi başına vergilendirme usulü de tepki ile karşılandı ve köylü isyanları yayılarak devam etti. Ancak, isyancılar, Rusya askeri birlikleri karşısında başarılı olamadılar ve isyanlar başarısızlıkla sonuçlandı. ${ }^{26}$

Rusya kolonizasyon politikasını uygularken, Avrupa'nın veya genel olarak Batının kullandığı "medeniyet götürme" argümanını kullanıyordu. Rus yönetici ve bürokratlarının bir kısmı, Kafkasya'da hâkim olabilmenin tek yolunun, Kafkasya dağlılarını baskı yolu ile kontrol altında tutmak olduğunu iddia ediyordu. Bu düşüncede olanlar, Kafkasya'ya medeniyet getirdikleri iddiasını taşımakla beraber, medeni olmayanlar olarak tanımladığı insanların yalnızca tek dilden anlayacaklarını öne sürüyorlardı. 1856'dan 1882 yılına kadar Rusya Dışişleri bakanı olarak görev yapan ve "şansölye" unvanına layık görülen Aleksandr Mihayloviç Gorçakov, Rusya'nın bakış açısını şu sözlerle açıklıyordu: "Asya halkları sadece güce saygı duymaktadırlar, aklın gücü ve eğitim henüz onlar üzerinde bir etkiye sahip değildir. ${ }^{\prime 27}$

Ruslaştırma politikası, Kafkasya'nın Rusya İmparatorluk yapısı ile her yönden bütünleşmesi amacını taşıyordu. Farklı kültürlerin ve birçok etnik grubun birlikte yaşadığı Kafkasya, bu özelliği ile İmparatorluğun Ruslaştırma politikasının selameti açısından bir tehdit unsuru olarak görülüyordu. ${ }^{28}$ XIX. yüzyılın ortalarından itibaren, hem Kuzey Kafkasya hem de Güney Kafkasya'nın Rusya Imparatorluğu'na her yönden entegre olması yönünde uygulamalar daha sık görülmeye başlandı. Ermeni-Gregoryan kiliseler ve Gürcü dili üzerindeki baskı arttı. Alınan bu önlemler, Gürcü ve Ermeni toplumlarının büyük tepkisini çekti. Gürcüler dillerini korumanın önemini daha güçlü savunmaya

\footnotetext{
${ }^{26}$ Hayri Çapraz, "19. Yüzyılın Illk Yarısında Gürcistan'da Politik ve Ekonomik Durum”, Yeni Türkiye Kafkaslar Özel Sayısı, Sayı 77, Temmuz-Aralık 2015, s. 469.

${ }^{27}$ Alizade, a.g.m., s. 161-162.

${ }^{28}$ Nikotin, a.g.m., s. 118.
}

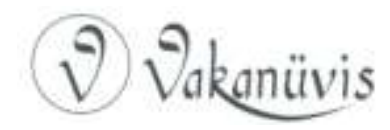


başladılar ${ }^{29}$ ve aynı şekilde Ermeniler arasında da bu politikalara karşı milli ve dini birlikteliği güçlendirecek adımlar atıldı. ${ }^{30}$

1860 'lı yılların sonundan itibaren Kafkasya'da Rus kökenli nüfusun artışını, bu nüfusun bölgede kalıcı olması için 1880-90'lı yıllarda yapılanlar ve bilhassa Rus kökenli köylü nüfusun iskânı izledi. 1889'da Hükümet bu yönde bir karar aldı ve Güney Kafkasya'ya Rus kökenli köylülerin yerleştirilmesini istedi. 1896-1897 yılları arasında Rusya İçişleri Bakanlığı, Rus kökenlilerin bölgede iskânı yönünde yeni adımlar attı. 1897 yılında Çernomorskaya (Karadeniz) Oblastı'ndaki iskân uygulamaları ile ilgili kanun yayınladı. 1899 ve 1900 yıllarında Rus kökenlilerin Kafkasya'nın diğer bölgelerindeki iskânlarını geçici olarak düzenleyen kararnameler yayınlandı. Bu süreçte Rusya Hükümeti'ni zorlayan en önemli sorun, Rus kökenli köylülere işlemeleri için verilecek arazinin temini hususunda idi. Bölgede devlet hazinesine ait yeterince arazi bulunmuyordu. Buna, Kafkasya yerlilerinin topraklarının bir kısmına el konularak çözüm bulunmaya çalışıldı. ${ }^{31}$

Rus köylülere toprak tahsisinin yerleşim yerleri içinde ve yakınında olması, Rus kültürü ve medeniyetinin yerel ahali arasına yayılması bakımından önemli sayılıyordu. Rusya'nın iç kesimlerinden gelen Rus köylüleri, kiliseleri ve okulları ile diğer halkları etki altına alabilecek ve bu anlamda Ruslaştırma politikasına katkı sunabileceklerdi.

Rusya Hükümeti'nin ve Kafkasya Genel Valiliği'nin, Kafkasya'da Rus kökenli nüfusu arttırma çabaları, beklenen ölçüde bir sonuç vermedi. 1905 yılına gelindiğinde toplamda birkaç bin Rus köylü nüfusun iskânı gerçekleştirilebildi. Kuzey Kafkasya'da devletin iskân uygulamaları yerel halkın tepkisi ile karşılaştı ve onların kendi arazilerini savunma refleksini ortaya çıkardı. Sonuç itibariyle arazi üzerinden yürüyen iskân politikaları, Rus unsurunun bölgede arttırılması yönünde bir sonuç vermekten ziyade, yerel halklar ve Kafkasya idaresi arasında gittikçe şiddetlenecek sorunları doğurdu. ${ }^{32}$

\footnotetext{
${ }^{29}$ M. V. Teplouhova, "Etno-Natsional'naya Politika v Rossiyskoy İmperii XIX-Naçala XX vv", Oykumena, Sayı: 2, Vladivostok 2011, s. 142.

${ }^{30}$ Ramazan Erhan Güllü, Ermeni Sorunu ve Istanbul Ermeni Patrikhanesi (1878-1923), Ankara 2015, s. 351.

${ }^{31}$ Tumakov, a.g.m., s. 31.

${ }^{32}$ Tumakov, a.g.m., s. 31-32.
}

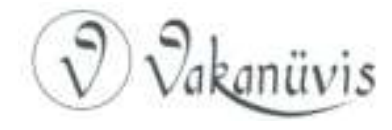


Ruslaştırma politikasının etkileri, İmparatorluğun birçok bölgesinde gözlemlenebiliyordu. Batı guberniyalarında (Minsk, Kiev vs.) eğitim sistemi en önemli araç olarak kullanılıyordu. Bu guberniyaların bir kısmında Leh kültürünün etkisi artarak devam ediyordu. Leh nüfus, ekonomik gücünün yanı sıra bölgenin kültür hayatına da nüfuz etmeyi amaçlıyorlardı. Kültürel olarak en büyük etki dini alanda görülüyordu. Rus soylular da bundan etkilenerek Katolik mezhebine geçmişlerdi. Bu anlamda batı guberniyalardaki "Rusifikatsiya" politikası, "Lehleştirme" nin etkisini kırmak ve Rus hâkimiyetini sağlamak olarak ortaya çıkmıştı. ${ }^{33}$ Kilise yönetimi, "Verootstupniki" (Dininden Dönenler) i bulmak ve vaftiz etmek için büyük çaba gösterdi. Eğitim alanında gayri Rus unsurlara ait olan okullar kontrol altında tutulmaya çalışıldı. ${ }^{34}$

"Eğitim" faktörü "Rusifikatsiya" politikasının en önemli dayanaklarındandı. XIX. yüzyıl boyunca ve XX. yüzyıl başlarında Rusya Hükümeti, farklı etnik gruplardan olanların eğitiminde devletin çıkarlarını ön planda olduğu bir kontrol sistemini uygulamaya çalıştı. Eğitim alanında Kafkasya'da, Rusya yönetiminin "dağlı" tabirini kullandığı Kuzey Kafkasya halklarına ayrı önem verildi. Eğitim, kendi amacının dışına çıkarak politik bir araç olarak, bilhassa Çerkezleri İmparatorluğun kurallarına uydurmak için kullanıldı. Eğitimin bu politik tarafı, müfredat bir yana herkese eşit olarak verilmemesinde ortaya çıkıyordu. Örneğin, XIX. yüzyılın sonlarında Dağıstan Oblastı'nda 26 okul var iken, Balkarların yaşadığı bölgede tek bir okul bile açılmamıştı. ${ }^{35}$

Kafkasya'nın Rus olmayan halklarını kültürel bakımdan Ruslaştırma, eğitim yoluyla yürütülmekteydi. Gayr-i Rus okullar, Halk Eğitimi Bakanlığı'na bağı olarak faaliyet gösteriyorlardı. 1884 yılında Rusya içişleri Bakanı D. A. Tolstoy'un girişimleri ile kilise ve manastırlar hariç olmak üzere Ermeni kilise ilkokullarında Rusça öğretilmesi ve bununla birlikte Rusya tarihi ve coğrafyası derslerinin Rusça okutulması talep

\footnotetext{
${ }^{33}$ Natalya Aleksandrovna Uvarova, "Gosudarstvennaya Politika v Sfere Obrazovaniya na Zapadnıh Okrainah Rossii v Kontse XIX-Naçale XX v. Kak Çast Natsional'noy Politiki", Vestnik Leningradskogo Gosudarstvennogo Universiteta im. A. C. Puşkina, Cilt: 4, Sayı: 1, Sankt-Peterburg 2012, s. 72.

${ }^{34}$ istoriya XIX Veka, Editörler: Lavissa ve Rambo, Cilt: 8, Moskva 1939, s. 296.

${ }^{35}$ Şebzuhova, a.g.m., s. 37.
} 
edildi. Rusya Hükümeti, bundan sonraki adım olarak 1892 yılında aldığı karar gereğince, Terek Oblastı'ndaki taşra okullarını ve Güney Kafkasya'daki Protestan Kilisesi okullarını Halk Eğitimi Bakanlığı'na devretti. ${ }^{36}$

Ruslaştırma politikasının eğitim sistemi ve diğer yönlerdeki aşırıcı uygulamaları, Ermeni din adamları tarafından tepki ile karşılandı. Bu tepkiyi sertlik yanlısı politikalar ile bastırmayı amaçlayan Kafkasya Genel Valisi S. A. Şeremetyev, 1895 yılı sonunda Çar'a hitaben gönderdiği yazısında, son on yıl içinde Ermeniler arasındaki ayrılıkçı hareketlere dikkat çekti. Şeremetyev, önlemlerin daha da genişletilmesi gerektiğini savunarak, Ermeni-Gregoryan kiliselerinin etki alanından Ermeni nüfusunu kurtarmanın önemini vurguladı. Onun önerisine göre, bütün bu kilise ve manastırların idaresinde bulunan okullar Halk Eğitimi Bakanlığı'na devredilmeliydi. Neticede 1897 yılında Ruhban Akademisi ve semineri hariç olmak üzere bütün ErmeniGregoryan kilise okulları bakanlığa devredildi ve bu süreçten sonra Ermeni kilise malları sorunu da ortaya çıkmış oldu. Ermeni din adamları kilise malları konusunu sürekli gündemde tuttular ve idareye şikâyetlerini ilettiler. Bu sorun, 1899 yılında Kafkasya Genel Valiliği'ne G. S. Golitsın'ın Çar'ın dikkatine sunduğu önerisi ile daha da derinleşti. $\mathrm{Bu}$ öneride, Ermeni-Gregoryan kiliselerinin tüm taşınmaz mal varlıklarına el konulması ve devlet hazinesine aktarılması yer alıyordu. Konu uzun süre tartışıldı ve nihayetinde 12 Haziran 1903 tarihinde yapılan toplantıda Çar II. Nikola, Ermeni-Gregoryan kiliselerinin sekülerleşmesi hakkındaki kanunu onayladı ve böylece kiliselerin mal varlıkları hazineye geçmiş oldu. ${ }^{37}$

Eğitim alanındaki reformlar ardı ardına geliyordu. Rus olmayanların eğitimine yönelik, "inorodtsılar için ilkokullar Hakkındaki Kanun" adıyla 1913 Temmuz ayında bir kanun yayınlandı. Bu kanunla Rusya Hükümeti, eğitim konusunda sert önlemler aldı. Eğitim alacakların

\footnotetext{
${ }^{36}$ Tumakov, a.g.m., s. 32

${ }^{37}$ Tumakov, a.g.m., s. 32
}

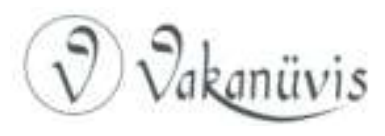


kimliği, öğretmenlerin ve derslerde kullanılacak materyallerin belirlendiği bir sistem uygulamaya konuldu. ${ }^{38}$

Kafkasya'nın yerel dillerinin geri plana itilmesi ve Rusça'nın eğitim sisteminde tek alternatif olarak sunulması, Kafkasya halklarının tepkisi ile karşılandı. Gence Şehir Mektebi'nde eğitim görenlerin ailelerinin, bu durumdan duydukları rahatsızlıkları dilekçe yoluyla Kafkasya Naibliği'ne bildirmeleri durumu yerel düzeyde yansıtması bakımından önemlidir. Dilekçede imzası olan 320 ismin etnik kökenleri dikkate alındığında, Ermeniler ve Türklerin ağırlıkta olduğu görülmektedir. Aileler tepkilerini şu sözlerle dile getiriyorlardı:" "Biz, Elisavetpol (Gence) Şehir Mektebi öğrencilerinin aileleri ve Elisavetpol şehri sakinleri olarak, mektebin ilk sınıflarında Rus dili öğretilmesinin verimli olmadığı görüşündeyiz. Rusça öğretmedeki başarı, ancak çocukların anadilinin yanında öğretilmesi ile mümkün olabilir. Ancak yalnızca Rus dilinin öğretimi tek başına bir metot olarak kabul edilemez."

Ailelerin bu tepkileri, kendi ifadeleri ile pedagoji uzmanlığı ile ilgili değildi. Ancak, aralarında entelektüel düzeyde bilgi sahibi olanların olduğunu belirterek, anadilin öğretilmemesinin eğitimde yerinin olmadığını vurguluyorlardı. Aileler, derslerin yalnızca Rusça ile yapılması ile ilgili kuralın derhal kaldırılmasını ve gelecek eğitim yılından itibaren anadillerde eğitim verilmesini talep ediyorlardı. ${ }^{40}$

Rus kökenli olmayanların kültür, yazı, edebiyat, tiyatro ve diğer faaliyetlerinde bir takım engeller çıkarılmakta ve bu bağlamda dillerini geliştirmelerinin önüne geçilmekteydi. ${ }^{41}$ XIX. yüzyıl Rusyası fikir adamlarından Mihail Nikiforoviç Katkov (1818-1887)'a göre, Rusya İmparatorluğu "milli devlet" olarak şekillenmeli idi. Katkov şu sözlerle bu düşüncesine açıklık getirmekteydi: ${ }^{42}$ "Rus olmayanlar da bu bağlamda kendi dillerini, dinlerini ve kültürel zenginliklerini koruyabilirlerdi. $\mathrm{Bu}$ durum devletin bütünlüğüne bir tehdit

\footnotetext{
${ }^{38}$ P. K. Daşkovskiy-E. A. Şerşnyöva, "Musulmanskoe Obrazovaniye v Zapadnoy Sibiri v XIX-naçale XX v.", İvestiya Altayskogo Gosudarstvennogo Universiteta, Sayı: 4-1, Barnaul 2011, s. 69.

${ }^{39}$ STSA, Fond 13, op. 6, d. 92, list 1.

${ }^{40}$ STSA, Fond 13 , op. 6, d. 92, list 4.

${ }^{41}$ Alizade, a.g.m., s. 163.

${ }^{42}$ Ragimova, a.g.m., s. 226.
} 
oluşturmuyordu, ancak tek bir hukuk, yönetim sisteminin yanı sıra devletin tek dili olmalıydı. Rusya için en büyük tehlike bünyesindeki milletlerin ayrılık fikri ve bağımsız devlet kurma hevesleridir".

Gürcü kökenli bazı yazarlar, Rusya İmparatorluğu'nun Gürcistan topraklarına egemen olması ile birlikte bölgenin birçok bakımdan geliştiğini kabul etmektedir. Onlara göre bu gelişim, Gürcü toplumunun bilinçlenmesine ve kendine güven duymasına katkı sağladı. Ancak Rusya'nın bazı dönemlerde Rus olmayan halklar üzerinde baskı kurma çabası ve onları Rus kimliğinde buluşmaya zorlaması birçok problemi beraberinde getirdi. Çarlık Rusyası'nın güçlü ve soylulardan oluşan bürokratlarının askeri politikalar uygulama arzusu ve Rus olmayan halkların asimilasyonuna yönelik girişimler, bu halkların kendilerini adeta bir açık hava hapishanesindeymiş gibi hissetmesine neden oluyordu. 1860'lı yıllardan itibaren Gürcü dilinin okullarda öğretilmesine sınırlandırmalar getirildi. 1890'lardan sonra resmi devlet kurumlarında Gürcüce kullanılmasını yasakladı. Baskıcı politikalar 1880 ve $90^{\prime}$ Iı yıllarda doruk noktasına ulaştı. ${ }^{43}$

Rusçanın tek dil olarak bütün alanlarda varlık göstermesini amaçlayan kararlar, ardı ardına alınmaya başlandı. 1880'li yıllardan itibaren Çar Hükümeti, Müslümanların dini eğitimi ile ilgilenen mollaların Rusça bilmelerini şart koştu. Bu şart 16 Temmuz 1888'de yasalaştı. 11 Ekim 1890'da Mollaların Rusça bildiklerini belgelemek için sınava girmelerini zorunlu hale getiren yasa kabul edildi. ${ }^{44}$

Bununla birlikte, eğitim politikasında istenen başarı yakalanamadı. Yerel zengin ve aydın beylerin gayretleriyle bir takım sonuçlar elde edilebildi ise de, Rusya'nın ilminskiy projesi gibi Ruslaştırmayı hedefleyen kültür politikaları bölgede derin etkiler gösteremedi. ${ }^{45}$

Kafkasya genel valileri, Çar'a sunulmak üzere Ruslaştırma politikasının Kafkasya'daki sonuçlarına dair raporlar hazırlıyorlardı. Kafkasya tarihinde önemli yeri olan Genel Vali S. A. Şeremetyev, 1895

\footnotetext{
${ }^{43}$ Oçerki İstorii Gruzii Guriziya v XIX. veke, Cilt: V, Tbilisi 1990, s. 337-338.

${ }^{44}$ Aleksandr Kobzev, "Tatarı-Musul'mane Srednego Povolj'ya: Etniçeskaya İdentiçnost' i Sluhi o Nasil'stvennom Kreşenii", Vestnik Evrazii, Sayı 3, Moskva 2004, s. 92.

${ }^{45}$ ilber Ortaylı, "XIX. Asırda Kafkasya ve Rusya", Sekizinci Askeri Tarih Semineri Bildileri I XIX. ve XX. Yüzyıllarda Türkiye ve Kafkaslar (24-26 Ekim 2001-Istanbul), Ankara, Genelkurmay Basım Evi, 2003, s. 121.
}

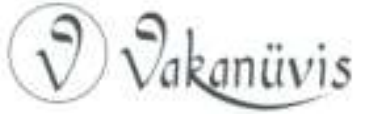


Aralık ayında hazırladığı raporunda "Kuzey Kafkasya'da Rus halkının egemenliği oldukça belirgin" diye yazıyordu. Şeremetyev, Güney Kafkasya'yı değerlendirirken, aynı ifadeleri kullanamıyordu. Ona göre, henüz Güney Kafkasya'da bu aşamaya varılamasa da, yakında aynı sonucu elde etmek mümkün olacaktı. Şeremetyev'den sonra Kafkasya Genel Valiliği görevini yürüten G. S. Golitsın, 1902 yılında Çar'a sunduğu raporunda Güney Kafkasya'da Ruslaştırma politikasının sonuçları itibariyle başarıdan uzak olduğunu ve bu konuda iyimser olmadığını açıklıyordu. Golitsın, Güney Kafkasya'daki farklı etnik grupların sosyal, ekonomik ve manevi yönden bir gelişim gösterdiklerinden bahsederek, milletleşme yolunda önemli yol aldıklarını aktarıyordu. Ona göre, özellikle içlerinde konar-göçerlerin de bulunduğu Müslüman halklar bu konuda mesafe almışlardı. Golitsın'a göre, bütün bu sonuçlara ve gelişmelere rağmen, Kafkasya'da İmparatorluğun pozisyonunu güçlendirme uygulamalarının doğruluğu tartışılmazdı. ${ }^{46}$

Rusifikatsiya veya Hıristiyanlaştırma politikası sonucunda, Müslüman nüfusun ne kadarının din değiştirdiğine dair 1897 ve 1906 yılı nüfus verileri dikkate alındığında, bu politikanın başarıya ulaştığı söylenemez. Hıristiyan nüfus miktarına bakıldığında, bu nüfusun etnik olarak Hıristiyan topluluklardan oluştuğu görülmektedir. ${ }^{47}$ Ancak, Kafkasya dışındaki diğer bölgelerde, Rusifikatsiya politikasının bazı sonuçlar aldığı söylenebilir. Örneğin Volga-Ural bölgesi Kilise idaresinin istatistiklerine dayandırılan verilerde 1866'dan 1905 yılına kadar toplam 6040 kişinin Müslümanlıktan Hıristiyanlığa geçtiği belirtilmektedir. ${ }^{48}$

Eğitim ve Rusça okuma-yazma oranı esas alındığında, Ruslaştırma politikasının başarıya ulaşamadığı görülmektedir. Rusçayı yaymak adına 1892 'de Tiflis'te bir kütüphane açıldığı ${ }^{49}$ ve okullarda Rusçanın zorunlu hale getirildiği uygulamalar sonrası oranlara bakıldığında bu durum

\footnotetext{
${ }^{46}$ Tumakov, a.g.m., s. 30.

47 Pervaya Vseobşaya Perepis' Naseleniya Rossiyskoy imperii 1897 g. LXIX. Tiflisskaya Guberniya, Sankt-Peterburg 1905, s. XIV-XV ve 80-81.

${ }^{48}$ Radik Ravil'yeviç İshakov, "Politika Religioznoy Unifikatsii Tatar-Musul'man VolgoUral'skogo Regiona v 1860-1905-h gg. Opıt İstoriko-Statistiçeskogo Analiza", Filologiya i Kul'tura, Sayı: 2 (28), Kazan 2012, s. 262.

${ }^{49}$ Kavkazskiy Kalendar na 1905 g, Tiflis 1904, (II. Otdel-Raznıya Svedeniya), s. 26.
}

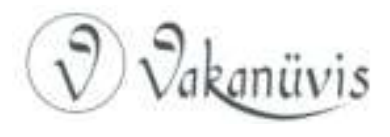


anlaşılmaktadır. Tiflis Guberniyası örneğinde, 1897 Nüfus Sayımına göre; Ermenilerden 105.035 erkekten 10.467'si; 91.154 kadından ise 5.460'ı Rusça okuyup yazabiliyordu. Gürcülerin okuma-yazma oranı nüfus miktarı dikkate alındığında diğer milletlere göre daha düşük kalmaktaydı. 251.596 erkekten 14.854'ü; 216.035 kadından ise 6.862'si Rusça okuyup yazabiliyordu. Guberniyada yaşayan Türklerin Rusça okuma-yazma oranı ise çok daha gerilerdeydi. 73.112 erkekten 790'।; 59.368 kadından ise yalnızca 95'i Rusça okuyup yazabiliyordu. ${ }^{50}$

1900'lü yıllara gelindiğinde Kafkasya'da, sosyalizm ve bağımsızlık yanlıları iktidara karşı eylemlere giriştiler. Petersburg, Kafkasya'daki siyasi ve sosyal gelişmelerin olumsuz etkilerini kırmaya yönelik adımlar atıyordu. Yerel halkın sahip olduğu toprağın yetersizliğinden duyulan rahatsızık, etnik gruplar arasındaki ayrılık ve zamanla düşmanlığın baş göstermesi, 1890'lı yıllardan itibaren Türkiye ve İran'dan Kafkasya'ya yapılan Ermeni göçleri gibi gelişmeler, Rusya Hükümeti tarafından yakından takip ediliyordu. Kafkasya'ya sosyal-ekonomik yönden etkileri olan bu gelişmeler, Kafkasya yönetiminin Petersburg'un istediği doğrultuda kararlar almasına yol açtı. Buna göre politika aşağıdaki başlıklara göre şekillenecekti: ${ }^{51}$

- Idari-hukuksal alanda merkezden tek uygulama,

- Avrupa ve Asya sınırlarında Rus unsurların arttırılması,

- Rus olmayanların kültür ve eğitim alanında etki altına alınması.

Rus olmayan milletler üzerindeki baskı, Kafkasya ile sınırlı kalmadı. 1902'de II. Nikola'nın emriyle, Finlandiya sıradan bir Rusya eyaleti statüsüne indirildi. Fin Diyet Meclisi ve Fin ordu birlikleri dağıtıldı. Lehlere ve Yahudilere karşı baskılar arttırıldı. ${ }^{52}$

Kafkasya'da işler yolunda gitmeyince, 1905 Şubatında idari yapı değişikliğine gidildi. Bu yapılanma idari anlamda Kafkasya Naibliği'nin yeniden teşekkülünden ibaret olmakla birlikte, politik olarak köklü değişimleri içeren bir dizi uygulamayı beraberinde getirdi.

\footnotetext{
${ }^{50}$ Pervaya Vseobşaya Perepis' Naseleniya Rossiyskoy Imperii 1897 g. LXIX. Tiflisskaya Guberniya, Sankt-Peterburg 1905, s. 108-109.

${ }^{51}$ Tumakov, a.g.m., s. 31.

52 Akdes Nimet Kurat, Rusya Tarihi Başlangıçtan 1917'ye Kadar, Ankara, Türk Tarih Kurumu Basımevi, 2010, s. 377.
} 
Kafkasya'daki ihtilal hareketleri ve halklar arasındaki çatışmalar, İmparatorluk yönetiminin bölgedeki baskıcı politikasından geri adım atmasına ve bir takım tavizler vermesine neden oldu. Bölgedeki gelişmelerin önlenemez bir hal alması ve vakit kaybetmeden bölgede düzenlemeler yapılmasının gerekliliğin anlaşııması üzerine, yeni oluşturulan idari yapılanma daha özerk bir yapıya kavuşturuldu. Bakanlıkların dahi Kafkasya'daki etkisi kırılarak, Kafkasya Naibine olağanüstü yetkiler verildi. Bu göreve atanan i. í. Vorontsov-Daşkov'un güçlü kişiliği de Kafkasya Naibliği'ni özel bir konuma oturttu. ${ }^{53}$

1905 yılına gelindiğinde Rusifikatsiya politikasından geri adım atıldı ve bir takım yasal düzenlemeler yapıldı. 17 Ekim 1905 manifestosu milliyet eksenli bir takım hakların tanınmasını sağladı. Milliyetçi çevreler milli dil ve kültürlerinin gelişimi noktasında bir süreliğine, nispeten daha rahat bir ortam buldular. ${ }^{54}$ Rusya Imparatorluğu'nda uzun yıllar iktidarı rahatsız eden "milliyetçi eğilimler", 1905 sonrasında daha çok gündem oluşturmaya başladı. ${ }^{55}$

Rusya iktidarı, İhtilal neticesinde farklı etnik kimliklere karşı daha esnek bir siyaset takip etti. Bu değişimin yansımaları aşağıdaki şekilde gerçekleşti: ${ }^{56}$

- $\quad$ Dil ve kültür alanındaki kısıtlama ve yasaklar kaldırıldı. Örneğin, Litvanya'da Latin alfabesi ile Litvanca yayın yapılmasına izin verildi,

- $\quad 1905$ 'de dinsel hoşgörü esasına bağlı olarak kiliseler arası ilişkileri düzenleyen kanunname yayınlandı,

- Hükümet dil politikasından taviz vermek durumunda kaldı,

- $\quad 17$ Ekim'deki manifestoda sivil toplum alanında önemli haklar verildi. Milli organizasyonlar, milli bağlantıların gelişmesi ve propaganda faaliyetleri konusunda özgürlük yönünde kararlar alındı.

Milliyetçi örgütlenmeler ve hareketler, bu tarihten sonra politik programlarını oluşturma adına büyük imkânlar elde ettiler. Çok partili hayat, milli örgütlenmelerde birlik, gazetelerde artış, farklı dillerde yayınlar ve bunların yanında daha fazla yayınlanmaya başlayan

\footnotetext{
${ }^{53}$ Tumakov, a.g.m., s. 30.

${ }^{54}$ Nikotin, a.g.m., s. 118.

${ }^{55}$ Ragimova, a.g.m., s. 134.

${ }^{56}$ Teplouhova, a.g.m., s. 143.
} 
manifesto ve bağımsızık içerikli çağrılar kamuoyunda yer tutmaya başladı. Milli içerikli bu faaliyetler, Bolşeviklerin ihtilal hazırlığı yaptığı zamanda, onların da dikkatini çekiyordu. Bolşevikler bu gruplarla işbirliği yapmaya hazırdılar ve onları proletaryanın dostu olarak gösteriyorlardı. ${ }^{57}$

intilal sonrası oluşan bu özgürlük ortamı, çok geçmeden yerini, 24 Kasım 1905'de alınan olağanüstü hal kanunlarına bıraktı. İmparatorluktaki bütün valiliklere iletilen kararlar gereğince, her türlü basın-yayın faaliyeti, örgütlenme, milliyetçi oluşumlar ve monarşiye zarar verebilecek her türlü eylem sıkı kontrol altında tutulacaktı. ${ }^{58}$

Sonuç olarak; XIX. yüzyılın başlarından XX. yüzyılın başlarına kadar Rusya İmparatorluğu'nun farkı yöntemler kullanarak uyguladığı Ruslaştırma politikası, inorodtsıları etkilediği gibi, bu politika sonucunda ortaya çıkan tepkileri engelleyemedi. Dil, edebiyat, kültür ve dini alandaki baskılar, halkların bir kısmını sindirmekle ve zamanla Ruslaştırmakla birlikte; bir kısmını kendi kimliğine daha fazla bağlanmaya ve daha sıkı birlikteliğe itti. İmparatorluk, siyasi ve sosyal gelişmelerini okurken, iç işlerinde tedirgin ve tedbirli davranmayı tercih etti. Bu tedirginlik neticesinde etnik olarak Rus olmayan halklara karşı bir güvensizlik oluştu ve onların monarşiye karşı ayaklanabilecekleri ihtimali iktidarın endişelerinin diri kalmasına neden oldu. Bu endişeden kaynaklanan önlemler, Kafkasya'daki siyasi ve sosyal olayları yönlendirici etkide bulundu. Gürcüler, Ermeniler ve Türk kökenli halklar üzerinde yürütülen siyaset, $X X$. yüzyılın başlarında milliyetçi eğilimleri arttırdı ve bağımsızık yönünde her millet kendi milli mücadelesini başlattı.

\section{Kaynakça}

Arşiv

Gürcistan Merkez Tarih Arşivi (STSA)

\footnotetext{
${ }^{57}$ Teplouhova, a.g.m., s. 143.

${ }^{58}$ STSA, Fond 13, op. 3, d. 10, list 42.
} 


\section{Araştırma Eserleri}

Acar, Kezban, Ortaçağ'dan Sovyet Devrimi'ne Rusya, i̇stanbul 2009.

Alizade, Zahida, "Natsional'no-Kolonial'naya Politika Tsarskovo Pravitel'stva na Tsentral'nom Kavkaze", Kavkaz i Globalizatsiya, Cilt: 1, Sayı: 5, 2007, s. 161-170.

Çapraz, Hayri, “19. Yüzyılın IIlk Yarısında Gürcistan'da Politik ve Ekonomik Durum", Yeni Türkiye Kafkaslar Özel Sayısı, Sayı 77, Temmuz-Aralık 2015, s. 467-472.

Daşkovskiy P. K.- Şerşnyöva E. A., "Musulmanskoe Obrazovaniye v Zapadnoy Sibiri v XIX-naçale XX v.", İvestiya Altayskogo Gosudarstvennogo Universiteta, Sayı: 4-1, Barnaul 2011, s. 68-71.

Georgiyeva, N. G., v.d., istoriçeskiy Slovar', Moskva 2015.

Güllü, Ramazan Erhan, Ermeni Sorunu ve istanbul Ermeni Patrikhanesi (1878-1923), Ankara 2015.

İshakov, Radik Ravil'yeviç, “Politika Religioznoy Unifikatsii TatarMusul'man Volgo-Ural'skogo Regiona v 1860-1905-h gg. Opıt istorikoStatistiçeskogo Analiza", Filologiya i Kul'tura, Sayı: 2 (28), Kazan 2012, s. 259263.

Istoriya XIX Veka, Editörler: Lavissa ve Rambo, Cilt: 8, Moskva 1939.

İvanov, A. A., "Lozung "Rossiya dilya Russkih» v Konservativnoy Misli Vtoroy Polovinı XIX Veka", Tetradi Po Konservatizmu", Sayı: 4, Moskva 2015, s. 34-42.

Kavkazskiy Kalendar na 1905 g, Tiflis 1904.

Kior, Viktor Borisoviç, “Gosudarstvennaya Natsional'naya Politika v Imperskoy Rossii", Vestnik Rossiyskogo Gosudarstvennogo Gumanitarnogo Universiteta, Sayı: 4, Moskva 2010, s. 204-218.

Kobahidze, Yelena İsaakovna, "K Voprosu o Roli Kolonizatsii v Politike «Rusifikatsii» Severnogo Kavkaza (Vtoraya Polovina XIX-Naçalo XX V.), Izvestiya Soigsi, Sayı: 13 (52), Vladikavkaz 2014, s. 9-16.

Kobzev, Aleksandr, "Tatarı-Musul'mane Srednego Povolj'ya: Etniçeskaya Identiçnost' i Sluhi o Nasil'stvennom Kreşenii", Vestnik Evrazii, Sayı 3, Moskva 2004, s. 89-98.

Kudryaşev, V. N., "Konservativno-Utopiçeskaya interpretatsiya Rusifikatorskoy Politiki v Kontse XIX-Naçale XX v", Vestnik Tomskogo Gosudastvennogo Universiteta, Sayı: 296, Tomsk 2017, s 96-101.

Kurat , Akdes Nimet, Rusya Tarihi Başlangıçtan 1917'ye Kadar, Ankara, Türk Tarih Kurumu Basımevi, 2010.

Lufyerçik, E. G., "Rusifikatsiya Kak Sredstvo Reşeniya Pol'skogo Voprosa Vo Vtoroy Polovine XIX-Naçale XX v.", Vesnik BDU, Sayı 3, s. 23.

Miller, Aleksey, Imperiya Romanovih i Natsionalizm, Moskva 2014. 
Nikotin, Dmitriy Alekseyeviç, “Natsional'nıy Faktor Transformatsii Politiçeskogo Rejima v Rossii: İstoriçeskiy Opıt i Sovremiyennost",, Istoriçeskiye, Filosofskiye, Politiçeskiye i Yuridiçeskiye Nauki, Kul'turologiya i iskusstvovedeniye. Voprosı Teorii i Praktiki, Sayı: 7-2 (57), 2015, s. 117-120.

Oçerki istorii Gruzii Guriziya v XIX. veke, Cilt: V, Tbilisi 1990.

Ortaylı, Ilber, "XIX. Asırda Kafkasya ve Rusya", Sekizinci Askeri Tarih Semineri Bildileri I XIX. ve XX. Yüzyıllarda Türkiye ve Kafkaslar (24-26 Ekim 2001-Istanbul), Ankara, Genelkurmay Basım Evi, 2003, s. 121. s. 119-125.

Pervaya Vseobşaya Perepis' Naseleniya Rossiyskoy Imperii 1897 g. LXIX. Tiflisskaya Guberniya, Sankt-Peterburg 1905.

Pulkin, Maksim Viktoroviç, "Tri Oblika Rusifikatsii v Karelii", Vestnik Evrazii, Sayı: 3, Moskva 2005, s. 107-125.

Ragimova, Perihanum Ferezullayevna, "Politika Rossiyskogo Pravitel'stva v Natsional'nıh Okrainah v XIX-Naçale XX vv.", Vestnik Krasnoyarskogo Gosudarstvennogo Pedagogiçeskogo Universiteta im. V. P. Astaf'eva, Sayı: 3, Krasnoyarsk 2010, s. 226-234.

Rossiya Entsiklopediçeskiy Slovar, Leningrad 1991.

Smirnov, N. A., Politika Rossii na Kavkaze XVI-XIX vekah, Moskva 1958.

Şebzuhova, F. H., “Osobennosti Upravleniya Natsional'nımi Okrainami v Rossiyskoy İmperii na Rubeje XIX-XX vv", Ejekvartalnıy Retsenziruemıy Nauçnıy Jurnal "Vestnik AGU", Sayı 3 (184), 2016, s. 34-42.

Şelkaçev, Aleksandr, "Obsujdeniye na Predsobornom Prisutstvii Voprosa ob Avtokefalii Gruzinskoy Tserkvi", Yejegodnaya Bogoslovskaya Konferentsiya Pravoslavnogo Svyatotihonovskogo Gumanitarnogo Universiteta, Sayı: 22, Moskva 2012, s. 50-53

Temizkan, Abdullah, "Kuzey Kafkasya Müridizmi, Müridizmin Yayılma Stratejisi ve Feodal Beylerle İlişkileri", Türk Dünyası Incelemeleri Dergisi, Cilt: IX, Sayı 2, s. 165-190.

Teplouhova, M. V., “Etno-Natsional'naya Politika v Rossiyskoy İmperii XIXNaçala XX vv", Oykumena, Sayı: 2, Vladivostok 2011, s. 139-144.

Thedore, Weeks R., "Russification: Word and Practice 1863-1914", Proceedings of the American Philosophical Society, Cilt 148, Sayı: 4, Aralık 2004, s. 471-489.

Tumakov, N. "Pervaya Russkaya Revolutsiya i Vosstanovleniye Namestniçestva na Kavkaze", Vestnik Ryazanskogo Universiteta Im. S.A. Yesenina, Sayı: 27, Ryazan 2010, s. 29-38.

Uvarova, Natalya Aleksandrovna, "Gosudarstvennaya Politika v Sfere Obrazovaniya na Zapadnıh Okrainah Rossii v Kontse XIX-Naçale XX v. Kak Çast Natsional'noy Politiki", Vestnik Leningradskogo Gosudarstvennogo Universiteta im. A. C. Puşkina, Cilt: 4, Sayı: 1, Sankt-Peterburg 2012, s. 71-77. 